\title{
Biosphere frontiers of subsurface life in the sedimented hydrothermal system of Guaymas Basin
}

\author{
Andreas Teske ${ }^{1}$, Amy V. Callaghan ${ }^{2}$ and Douglas E. LaRowe ${ }^{3}$ \\ ${ }^{1}$ Department of Marine Sciences, University of North Carolina at Chapel Hill, Chapel Hill, NC, USA \\ 2 Department of Microbiology and Plant Biology, University of Oklahoma, Norman, OK, USA \\ ${ }^{3}$ Department of Earth Sciences, University of Southern California, Los Angeles, CA, USA
}

\section{Edited by:}

Mark Alexander Lever, Aarhus

University, Denmark

\section{Reviewed by:}

Purificación López-García, Centre

National de la Recherche Scientifique,

France

D'Arcy Renee Meyer-Dombard,

University of Illinois at Chicago, USA

\section{*Correspondence:}

Andreas Teske, Department of Marine Sciences, University of North Carolina at Chapel Hill, Chapel Hill, NC 27599, USA

e-mail: teske@email.unc.edu
Temperature is one of the key constraints on the spatial extent, physiological and phylogenetic diversity, and biogeochemical function of subsurface life. A model system to explore these interrelationships should offer a suitable range of geochemical regimes, carbon substrates and temperature gradients under which microbial life can generate energy and sustain itself. In this theory and hypothesis article, we make the case for the hydrothermally heated sediments of Guaymas Basin in the Gulf of California as a suitable model system where extensive temperature and geochemical gradients create distinct niches for active microbial populations in the hydrothermally influenced sedimentary subsurface that in turn intercept and process hydrothermally generated carbon sources. We synthesize the evidence for high-temperature microbial methane cycling and sulfate reduction at Guaymas Basin - with an eye on sulfate-dependent oxidation of abundant alkanes - and demonstrate the energetic feasibility of these latter types of deep subsurface life in previously drilled Guaymas Basin locations of Deep-Sea Drilling Project 64.

Keywords: subsurface, Guaymas Basin, hydrothermal, methane, alkane oxidation, energy metabolism

\section{THE GUAYMAS MODEL SYSTEM}

The Guaymas Basin in the Gulf of California is a young marginal rift basin characterized by active seafloor spreading and rapid deposition of organic-rich sediments from highly productive overlying waters. The juxtaposition of active seafloor spreading and thick sedimentary sequences has created a dynamic environment where tightly linked physical, chemical, and biological processes regulate the cycling of sedimentary carbon. In Guaymas Basin, deeply emplaced volcanic sills originating at the spreading center have indurated and hydrothermally altered their surrounding sediment matrix, and continue to shape hydrothermal circulation patterns today (Einsele et al., 1980; Lonsdale and Becker, 1985). Buried organic matter is transformed quickly into hydrocarbons; Guaymas Basin hydrocarbons are young enough to be ${ }^{14} \mathrm{C}$-dated and have an average radiocarbon age of approximately 5000 years (Peter etal., 1991). Hydrothermal pyrolysis transforms and mobilizes a major proportion of subsurface carbon sources: the organic carbon content of approx. 3-4 wt $\%$ in surficial Guaymas Basin sediments (De la Lanza-Espino and Soto, 1999) is reduced to $1-2 \%$ in subsurface sediments below sills (Rullkötter et al., 1982; Simoneit and Bode, 1982). Hydrothermal alteration of buried sedimentary organic matter generates petroleum compounds including complex mixtures of linear, branched and cycloalkanes, hopanes, steranes, diasteranes, olefins, and polynuclear aromatic hydrocarbons (PAHs; Simoneit and Lonsdale, 1982; Kawka and Simoneit, 1987; Didyk and Simoneit, 1989), low-molecular weight alkanes (Bazylinski et al., 1988), organic acids (Martens, 1990), and ammonia (Von Damm et al., 1985). This mixture of substrates permeates the sediments and sustains extensive microbial communities that - among other processes - mediate methanogenesis (Welhan, 1988), methane oxidation (Kallmeyer and Boetius, 2004), and sulfate reduction (Jørgensen et al., 1990; Jørgensen et al., 1992; Elsgaard et al., 1994; Weber and Jørgensen, 2002; Kallmeyer et al., 2003). Hydrothermal mobilization also re-injects buried carbon, esp. methane, into the biosphere, a process with climate history relevance (Lizarralde et al., 2011).

Guaymas Basin provides a classic example for young spreading centers that are often thickly sedimented due to their proximity to terrigenous sediment sources and the influence of coastal upwelling; modern examples include the Red Sea, the Gulf of Aden, the South China Sea, the East Sea/Sea of Japan, and the Aegean Sea. The interplay of geochemi$\mathrm{cal}$, thermal and microbial forces that mobilize and assimilate carbon in the Guaymas Basin sediments provides a model system for exploring the extent, activity, biogeography and metabolic capabilities of subsurface microbial life within the extensive chemical and physical gradients of a young spreading center (Figure 1). Also, hydrocarbon-rich Guaymas Basin has particular promise for in-depth investigations of anaerobic hydrocarbon transformation, and the diversity and evolution of hydrocarbon-degrading microorganisms and pathways. Microbes capable of intercepting, oxidizing or assimilating hydrocarbons could attenuate the hydrothermally catalyzed mobilization and loss of buried carbon from hydrothermal sediments (Lizarralde et al., 2011). Yet, the extent and function of subsurface life in Guaymas Basin has not been probed since Leg 64 of the Deep-Sea Drilling Program (DSDP) targeted the massive sediments of Guaymas Basin (Curray et al., 1979; Curray and Moore, 1982) and demonstrated microbial methanogenesis in the deep 


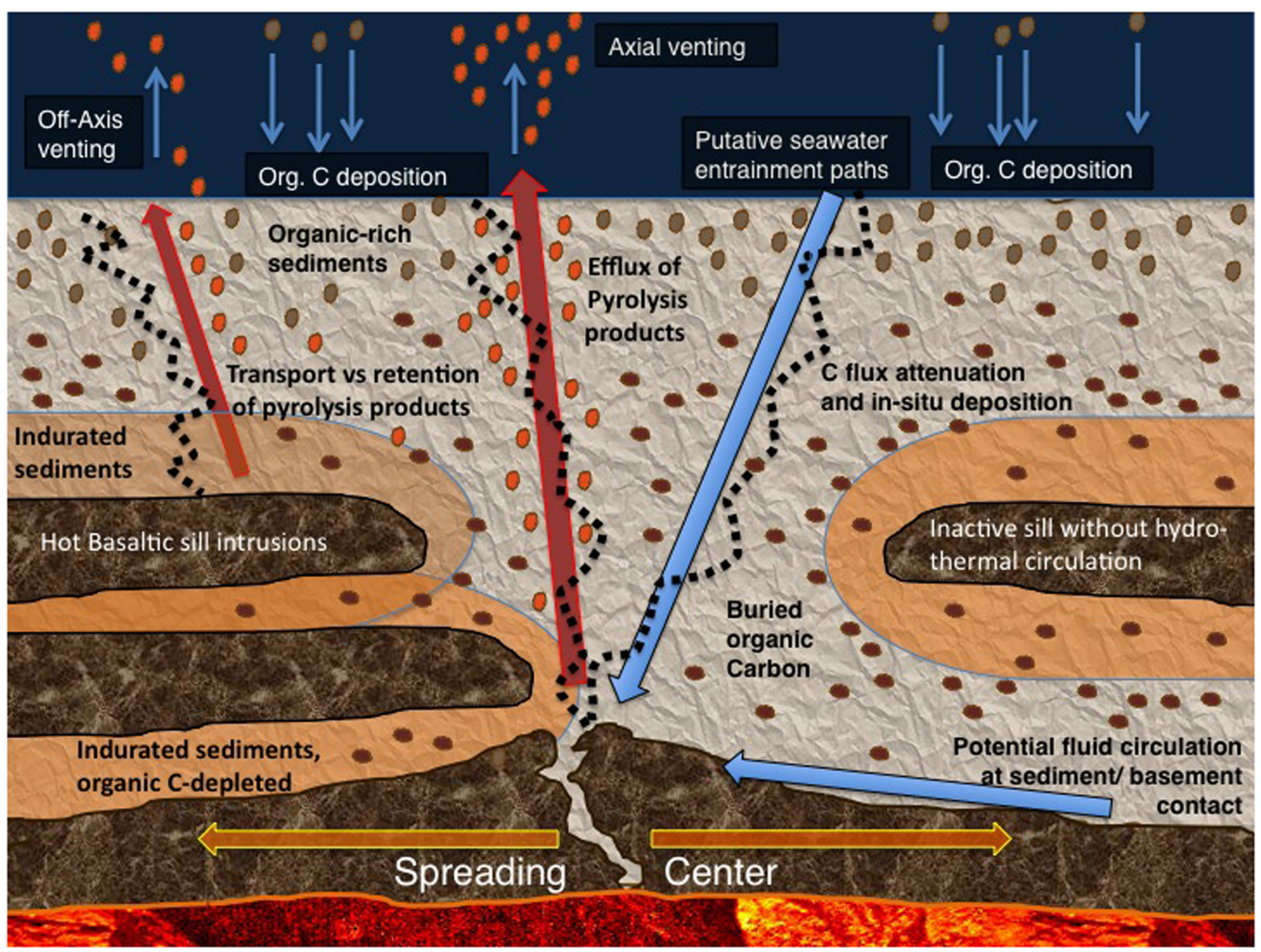

FIGURE 1 | Schematic representation of the Guaymas Basin subsurface with deep basement, sills, sediments, marine sedimentation and organic carbon input (brown drops), immobilized carbon in the sediment (dark-brown horizontal pellets), volatile pyrolysis products (orange drops), and hypothetical fluid flow pathways (arrows). The black dotted lines indicate potential flow paths along fracture lines in the sediments; actually existing flow paths vary in location and vertical extent. sediment column (Galimov and Simoneit, 1982; Oremland et al., 1982).

\section{THE SURFACE LAYER}

Diverse and abundant microbial life in the surficial hydrothermal sediments of Guaymas Basin is well-documented (reviewed in Amend and Teske, 2005). This survey of temperature and chemical regimes of Guaymas Basin starts at the sediment surface, where conspicuous microbial mats provide the highly visible surface expression of complex subsurface processes. Here, cold deep-sea bottom water supplies oxygen and nitrate; these oxidants permeate the surficial sediments not only by molecular diffusion, but are entrained by hydrothermal circulation (Gundersen et al., 1992). The nitrate influx into the upper sediment layers sustains active denitrifying microbial communities, which are inhibited by sulfide exposure (Bowles et al., 2012). Microbial mats of filamentous sulfur-oxidizing bacteria (family Beggiatoaceae) cover the seafloor in conspicuous patches (Jannasch et al., 1989). In shipboard experiments with fresh microbial mat samples, these bacteria take up autotrophic dissolved inorganic carbon (DIC), preferentially at moderate temperatures around $20^{\circ} \mathrm{C}$ (Nelson et al., 1989). These mats grow specifically in the areas where sulfidic fluids rich in DIC, methane, and low-molecular-weight organic compounds form gradients within the porewater right underneath the sediment surface, indicating near-surface consumption of these substrates (McKay etal., 2012). In situ temperature measurements in and beneath these oxygen- and nitrate-dependent sulfur-oxidizing mats indicate cool temperatures (near $10-15^{\circ} \mathrm{C}$ ) right at the sediment surface within the mat, although the temperatures within the underlying sediments rise quickly and can reach $>100^{\circ} \mathrm{C}$ within $30 \mathrm{~cm}$ depth (McKay et al., 2012). Genome sequencing of individual filaments supports a sulfur-oxidizing, nitrate-respiring metabolism with both autotrophic and heterotrophic capabilities (MacGregor et al., 2013a,b,c).

\section{THE MICROBIAL GAUNTLET}

To map the unexplored taxonomic and physiological diversity of subsurface life in Guaymas Basin in relation to key chemical and thermal controls, the concept of the "Microbial Gauntlet" is helpful: Hydrothermally transformed organic substrates, 
or pyrolysis products from the hot end of hydrothermal gradients, are gradually processed and assimilated by subsurface microbial communities that populate the subsurface environment as soon as in situ temperatures and electron acceptor availability become compatible with their physiological requirements; microbial processing continues with cooler temperatures and increased electron acceptor availability towards the sediment surface, where seepage of hydrothermal fluids fuels abundant microbial mats (Figure 2). In this view, the microbial mats of Guaymas Basin represent the last stage of the microbial gauntlet in the sediments, as they intercept energy and carbon sources from hydrothermally active sediment and modulate microbial oxidation and carbon assimilation processes at the sediment/water interface.

\section{HIGH-TEMPERATURE METHANE AND SULFUR CYCLING}

The microbial processes that generate, consume or modify the carbon and energy sources that are available at the sediment surface (for example sulfide, DIC and methane) extend into the hydrothermal sediments of Guaymas Basin. Given the strong hydrothermal gradients at Guaymas Basin, it is likely that the depth range of microbial processes is to a large part determined by temperature. By extrapolating from current evidence for microorganisms and microbial processes in surficial sediments (summarized in the following paragraphs), we hypothesize that the subsurface is permeated most deeply by microbial groups that tolerate maximal in situ temperatures and extremely reduced redox regimes. This is the domain of microbial methane and sulfur cycling; the temperature limits on these processes are outlined here.

Methanogens in Guaymas Basin sediments include numerous hyperthermophilic lineages, with the well-studied examples Methanopyrus kandleri, which has a growth limit at $110^{\circ} \mathrm{C}$ (Kurr et al., 1991; near $120^{\circ} \mathrm{C}$ under deep-sea in situ pressure, Takai et al., 2008), and Methanocaldococcus jannaschii and related strains growing at temperatures of $80-90^{\circ} \mathrm{C}$ (Jones et al., 1983, 1989; Jeanthon et al., 1999). Microbial community analyses, in situ temperature gradients, and porewater geochemistry from pushcores of surficial sediments have detected specific, phylogenetically distinct ANME-1 populations of methanotrophic archaea in hightemperature sediments at hyperthermophilic in situ temperatures (ranging from ca. 60 to $>90^{\circ} \mathrm{C}$ ), and concomitant $\delta^{13} \mathrm{C}-\mathrm{CH}_{4}$ and DIC signatures of biogenic methane oxidation (Biddle et al., 2012). These high-temperature ANMEs are not limited to Guaymas Basin, but are widespread in methane-rich hydrothermal fluids at different vent sites (Merkel et al., 2012). Laboratory incubations and enrichments of sulfate-dependent, anaerobic methane oxidizing microbial populations from Guaymas Basin indicated a temperature limit of ca. $70^{\circ} \mathrm{C}$ (although with different ANME1 populations), and preferred temperatures around $50-60^{\circ} \mathrm{C}$ for thermophilic methane oxidizers (Holler et al., 2011). Highpressure incubations with Guaymas sediment even showed low methane-oxidizing activities near $80^{\circ} \mathrm{C}$ (Kallmeyer and Boetius, 2004). When comparing the temperature ranges for methanogenesis and anaerobic (sulfate-dependent) methane oxidation,
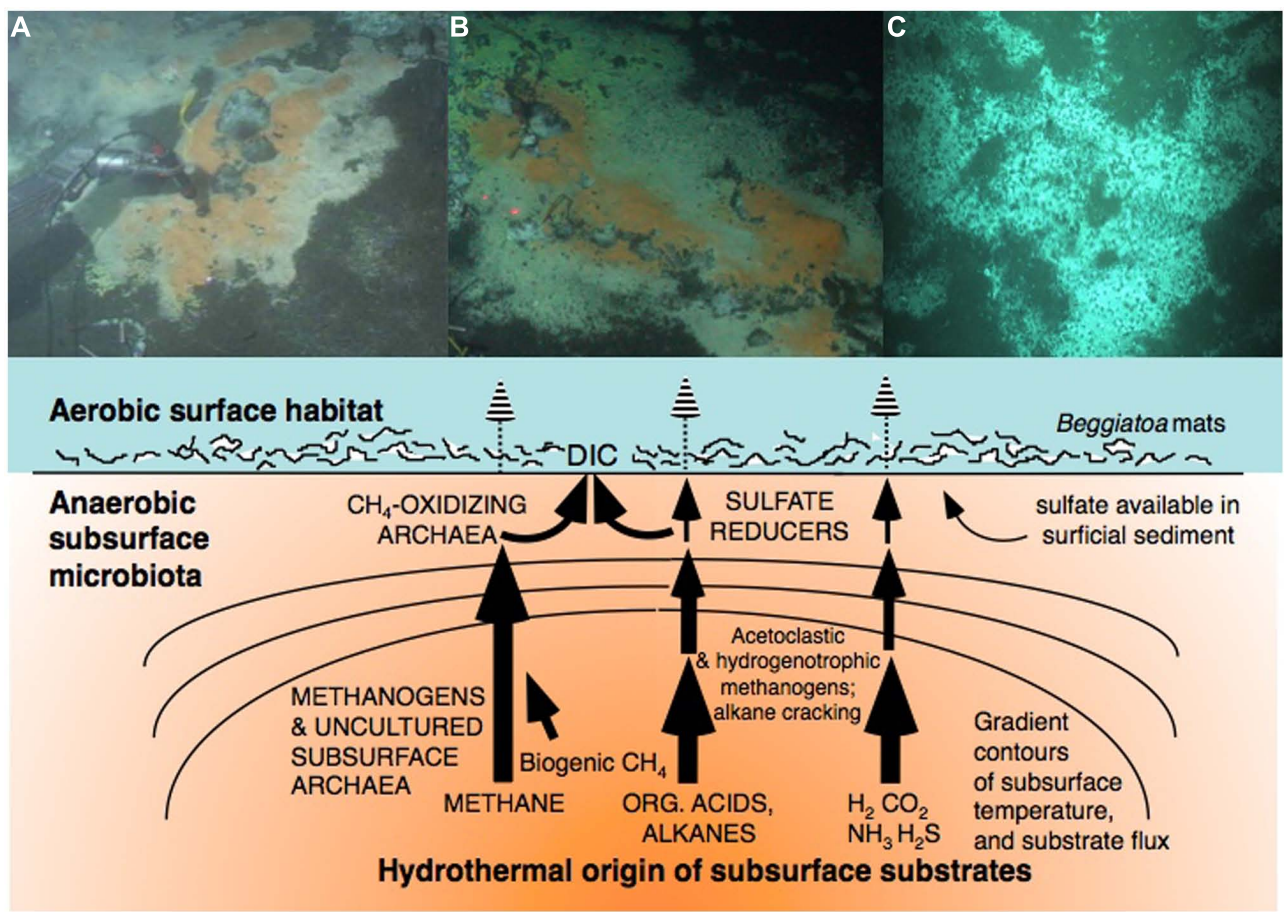

FIGURE 2 | The microbial gauntlet modifies the fluxes of deep carbon and gasses toward the sediment surface. The top row shows examples for sulfur-oxidizing microbial mats dominated by filamentous Beggiatoaceae at well-documented hydrothermal seepage hot spots on-axis (A, Biddle etal., 2012; B, McKay etal., 2012) and off-axis in Guaymas Basin (C, Lizarralde etal., 2011). The Beggiatoaceae mats intercept DIC for autotrophic assimilation, and sulfide for oxidation with nitrate as the electron acceptor. 
methanogenesis persists into higher temperatures $\left(80-110^{\circ} \mathrm{C}\right)$ than methane oxidation; the latter reactions might also be limited by the temperature ceiling of sulfate-reducing syntrophs that participate in methane oxidation (Holler et al., 2011).

The thermal habitat requirements for sulfate- and sulfurreducing archaea show a similar, if less pronounced, temperature gap. Different strains and species of the archaeal sulfate reducer Archaeoglobus (also isolated from Guaymas Basin; Burggraf et al., 1990) have upper temperature limits near $85-90^{\circ} \mathrm{C}$ (reviewed in Amend and Teske, 2005). Consistent with this temperature range of cultured hyperthermophilic sulfate reducers, microbial sulfate reduction in Guaymas Basin sediments has been detected at temperatures near $90^{\circ} \mathrm{C}$ (Elsgaard et al., 1994; Jørgensen et al., 1990; but note a $120^{\circ} \mathrm{C}$ outlier, Jørgensen et al., 1992). In contrast, the elemental sulfur-reducing Thermococcales of Guaymas Basin include Thermococcus and Pyrococcus strains that grow at temperatures near $100^{\circ} \mathrm{C}$ (Jannasch et al., 1992; Huber et al., 1995; Canganella et al., 1998; Edgcomb et al., 2007; Teske et al., 2009; Wang et al., 2011), approx. $10-15^{\circ} \mathrm{C}$ higher than the sulfate reducers. Differences in the thermal stability of the cellular components and enzymes of sulfate vs. sulfur reduction might account for this gap. So far, these methane- and sulfur-cycling hyperthermophiles have been isolated from surficial hydrothermal sediments of Guaymas Basin; similar organisms may exist in the deep surface of Guaymas Basin, given the detection of Thermococcales in deep hot oil fields (L'Haridon et al., 1995), and, together with different ANME archaea, in very deep, geothermally heated marine sediments (Roussel et al., 2008).

\section{HIGH-TEMPERATURE HYDROCARBON OXIDATION}

In the upper sediment column, towards the sediment surface, and under generally more moderate environmental conditions at off-axis locations, less extremophilic microbial groups will gain a foothold, increase overall microbial biomass and activity, and broaden the chemical spectrum of microbially catalyzed reactions. Here we call attention to the mesophilic and thermophilic sulfate-reducing bacteria that anaerobically oxidize the diverse hydrocarbons in Guaymas Basin sediments and play a key role in the selective degradation of specific substrate classes, such as alkanes (Bazylinski et al., 1988). Guaymas Basin has developed into a preeminent sampling area to enrich and isolate novel alkane- and aromatic-degrading sulfate reducers that use different biochemical strategies to harness energy from hydrocarbons. The first aromatics-oxidizing, sulfate-reducing isolate from Guaymas Basin sediments, Desulfothermus naphthae strain TD3, grows optimally between 55 and $65^{\circ} \mathrm{C}$, and couples the oxidation of $\mathrm{C}_{6}-\mathrm{C}_{16}$ alkanes and 3-methyloctane to sulfate reduction, although its specific alkane activation and degradation mechanism remains unknown (Rüter et al., 1994; Ehrenreich, 1996). Shortly after the isolation of TD3, a benzene-utilizing enrichment culture was obtained from Guaymas sediments (Phelps et al., 1996), which contained phylotypes that affiliate with members of the Desulfobacterium anilini and Desulfobacter clusters (Phelps et al., 1998); one of these Desulfobacterium phylotypes (SB-21) is possibly involved in benzene activation (Oka et al., 2008). Although benzoate was detected as an intermediate in this enrichment culture, the source of the carboxyl group remains unidentified (Phelps et al., 2001). The sulfate-reducing strain EbS7, isolated from Guaymas sediments, is capable of ethylbenzene degradation via addition to fumarate (i.e., "fumarate addition"; Kniemeyer et al., 2003). More recently, several cultures utilizing gaseous alkanes at mesophilic and thermophilic conditions were established with Guaymas Basin sediments. The culture Propane60-GuB grows at $60^{\circ} \mathrm{C}$ on propane via fumarate addition, and phylogenetic analysis revealed that the dominant phylotype belongs to the genus Desulfotomaculum (Kniemeyer et al., 2007). From the same study, another enrichment culture that utilizes butane at $60^{\circ} \mathrm{C}$ yielded dominant phylotypes that appear to be closely related to a deeply branching bacterial lineage dominated by clones from Guaymas Basin and other deep-sea sediment sites (Teske et al., 2002; Dhillon et al., 2003; synonymous with "Hot seep cluster," Holler et al., 2011). The phylogenetic affiliation of this cluster is a matter of debate; while it was included among the Deltaproteobacteria by Holler et al. (2011), repeated tests with multiphylum full-length 16S rRNA gene alignments indicated that this group forms its own deeply branching bacterial lineage (Teske et al., 2002; McKay, 2014).

Taken together, these studies indicate a mesophilic to thermophilic temperature range (up to $65^{\circ} \mathrm{C}$ ) for alkane- and aromatics-degrading sulfate reducers in Guaymas Basin, and suggest that hydrocarbons can be microbially remineralized in moderately heated sediments. As a caveat, sulfate may not be strictly necessary when sulfate reducers that can utilize alkanes also grow in syntrophic consortia (Callaghan et al., 2012). Further, it has to be emphasized that the thermophilic spectrum of sulfatereducing bacteria is still poorly known. For example, a comparative CARD-FISH hybridization study of Deltaproteobacteria in different cold seep sediments and in Guaymas Basin hydrothermal sediments indicated that Guaymas Basin harbored reduced proportions of Desulfosarcinaceae and Desulfobulbaceae but the highest proportion of unidentified Deltaproteobacteria that did not react with group-specific $16 \mathrm{~S}$ rRNA hybridization probes (ca. 44\%), suggesting unexplored deltaproteobacterial diversity in Guaymas Basin (Kleindienst et al., 2012). The recent description of a novel autotrophic and thermophilic sulfur-disproportionating Deltaproteobacterium, Dissulfuribacter thermophilus, underscores the unexhausted potential of hydrothermal sediments for pure culture research (Slobodkin et al., 2013).

Last but not least, we are also calling attention to the possibility that hydrocarbon oxidation can be carried out at substantially higher temperatures, in the hyperthermophilic spectrum near and above $80^{\circ} \mathrm{C}$. Some hyperthermophilic archaea have been characterized with respect to the anaerobic activation of nonmethane hydrocarbons. Although not isolated from Guaymas Basin, Archaeoglobus fulgidus strain VC-16 serves as a model archaeal strain of $n$-alkene (Khelifi et al., 2010) and alkane degradation (Khelifi etal., 2014). The hyperthermophilic archaeon Ferroglobus placidus strain AEDII12DO DSM 10642, isolated from a sand-water mixture collected near Porto di Levante, Vulcano, Italy (Hafenbradl et al., 1996), couples the reduction of Fe(III) to the oxidation of aromatic compounds, including benzene; it is proposed that the molecule is activated by carboxylation (Tor and Lovley, 2001; Holmes et al., 2011). Thermococcus sibiricus, isolated from a Siberian oil field, can grow anaerobically on hexadecane 
at $78^{\circ} \mathrm{C}$, although the activation mechanism is still unknown (Mardanov et al., 2009). Given the isolation of Archaeoglobus spp. (Burggraf et al., 1990), and other hyperthermophilic archaea from Guaymas Basin, including Thermococcus spp, Pyrococcus (Jannasch et al., 1992; Huber et al., 1995; Canganella et al., 1998; Wang et al., 2011), and Geoglobus (Kashefi et al., 2002), Guaymas Basin serves as an obvious platform to reconcile the gaps in our understanding of anaerobic hydrocarbon transformation with the elucidation of the metabolic versatility of Archaea.

\section{BIOCHEMICAL POTENTIAL FOR HYDROCARBON OXIDATION}

Guaymas Basin offers a test case where the temperature range not only of specific organisms but of their biochemistry can be tested; here we focus on sulfate-reducing alkane oxidation since the organisms, substrates and processes are well-documented in Guaymas Basin. Alkanes are among the least reactive hydrocarbons due to their strong $\mathrm{C}-\mathrm{H}$ bonds. With respect to non-methane alkanes, biodegradation is often initiated via addition of alkanes to the double bond of fumarate ("fumarate addition") to produce alkylsuccinates (Kropp et al., 2000). The process is analogous to the addition of aromatic hydrocarbons to fumarate by benzylsuccinate synthase (BSS; Leuthner et al., 1998). Fumarate addition has been reported for both linear alkanes in the C3C16 range (for review see Callaghan, 2013a) and for cycloalkanes (Rios-Hernandez et al., 2003; Musat et al., 2010). This mechanism may also be involved in the activation of solid paraffins, although the requisite metabolites have not been detected (Callaghan et al., 2010; Davidova et al., 2011). The addition of alkanes to fumarate is presumably catalyzed by the glycyl radical enzyme alkylsuccinate synthase (ASS; Callaghan et al., 2008b), also known as methylalkylsuccinate synthase (MAS; Grundmann etal., 2008), which has been used as a metabolic biomarker of anaerobic alkane transformation in a variety of isolates, enrichment cultures, and hydrocarbon-impacted environments (Callaghan, 2013a). Alternative mechanisms of anaerobic alkane activation by sulfatereducing bacteria include carboxylation of $n$-alkanes, previously proposed for the sulfate-reducing isolate, Desulfococcus oleovorans $\mathrm{Hxd} 3$, and a nitrate-reducing enrichment culture growing on $n$-hexadecane (So et al., 2003; Callaghan et al., 2009). Genome sequencing of D. oleovorans inferred an enzyme complex similar to ethylbenzene dehydrogenase (Callaghan et al., 2008a), and recent investigations of strain $\mathrm{Hxd} 3$ suggest that this enzyme may play a role in alkane activation via anaerobic hydroxylation (Sünwoldt et al., 2012; Heider and Schühle, 2013). If proven, this homolog of ethylbenzene dehydrogenase may serve as a new in situ biomarker of anaerobic alkane transformation. Guaymas Basin sediments and enrichments offer the opportunity to "bioprospect" for these diagnostic enzymes and their genes.

An important feature of the Guaymas Basin is the complex mixture of alkanes, including methane. Methane concentrations in Guaymas Basin vent fluids range from 12 to $16 \mathrm{mM}$ (Welhan, 1988). The conspicuous isotopic signatures of anaerobic methane oxidation (AOM) in Guaymas Basin sediments coincide with gene-based detection of ANME archaea; microbial methane oxidation changes $\delta^{13} \mathrm{C}-\mathrm{CH}_{4}$ from a background value of ca. $-43 \%$ o in hydrothermal sediments towards -20 or $-15 \%$ o (Biddle et al., 2012). Elucidating the mechanism(s) of AOM is considered to be the "holy grail" of anaerobic hydrocarbon metabolism because it would provide insight to the cycling of the most important hydrocarbon on Earth, particularly with respect to methane sinks. To date, three hypotheses regarding AOM include: (1) "reverse methanogenesis" (Zehnder and Brock, 1979; Hoehler et al., 1994; Hallam et al., 2004), which is catalyzed by a homolog of methylcoenzyme M reductase (MCR; Krüger et al., 2003; Scheller et al., 2010), (2) "intra-aerobic denitrification," in which dinitrogen and molecular oxygen are produced from two nitric oxide molecules, the oxygen being used to functionalize methane by a methane monooxygenase (Ettwig et al., 2010), and (3) AOM and sulfate reduction being catalyzed by anaerobic methanotrophic archaea (ANME-2) via the reduction of sulfate to zero-valent sulfur $\left(\mathrm{S}^{0}\right)$ and possibly to sulfide (Milucka et al., 2012). Alternatively, the addition of non-methane alkanes to fumarate has also prompted speculation that methane could be functionalized via fumarate addition, and the thermodynamic constraints have been hotly debated (for review see Callaghan, 2013a). Interestingly, methylsuccinate has been detected in sulfate-reducing and methanogenic subsurface environments such as oilfields and coal beds (Duncan et al., 2009; Gieg et al., 2010; Wawrik et al., 2012). However, no studies have definitely linked the detection of methylsuccinate with genetic biomarkers or other evidence indicative of a fumarate addition pathway.

Due to the ubiquity of methane, the persistence of methanogenic activity even in deep sediments, and the high temperature ranges of microbial methanogenesis and methane oxidation, the Guaymas Basin sediments provide a model system to investigate these distinct methane oxidation pathways in the deep subsurface.

\section{DETECTING METABOLIC POTENTIAL AND ACTIVITY IN GUAYMAS BASIN}

Metabolite profiling, or metabolomics, has been a powerful tool used to elucidate the requisite metabolic pathways of anaerobic hydrocarbon activation (Callaghan, 2013b). Metabolomic studies and the discovery of enzymes involved in anaerobic hydrocarbon activation were together highly relevant for investigations of both natural and engineered systems, namely in situ investigations of contaminated groundwater and oil production water (Callaghan, 2013b). With a growing database of metabolic biomarkers and functional key genes in hand, more challenging environments are now being explored, such as coal-beds (Wawrik et al., 2012), the deep-sea sediments of the Gulf of Mexico (Kimes et al., 2013), and the oil-soaked sands associated with the Deepwater Horizon oil spill (Aeppli et al., 2012). Thus far, only a few studies have investigated Guaymas Basin for marker genes of anaerobic hydrocarbon degradation. In sediment samples from below a microbial mat in the Guaymas Basin (collected on Alvin dive 4573), two ASS genotypes (assA) and two (2-naphthylmethyl)succinate synthase genotypes $(n m s A)$ were detected using targeted primers (von Netzer et al., 2013). In another study, metagenome analysis of an oil-immersed chimney in Guaymas Basin resulted in the detection of genes involved in anaerobic hydrocarbon activation (ass A, bss A, and ethylbenzene dehydrogenase), although some inconsistencies in the descriptions of the model organisms and their hydrocarbon activation genes have to be noted (He et al., 2013). These 
functional gene surveys have focused mainly on enzymes catalyzing fumarate addition or anaerobic hydroxylation. However, with the recent discoveries of other putative marker genes such as naphthalene carboxylase (Bergmann et al., 2011; Mouttaki et al., 2012) and benzene carboxylase (Abu Laban et al., 2010; Holmes et al., 2011), the potential for different hydrocarbon activation strategies can be investigated in situ via metagenomic and/or metatranscriptomic approaches. Although Guaymas Basin has not been mined in situ for anaerobic hydrocarbon intermediates via metabolite analysis, functional key genes provide targets for metabolite profiling efforts. Given recent advances in our understanding of the biochemical pathways that govern anaerobic hydrocarbon oxidation, we are well poised to exploit omic-based methodologies to address questions regarding the metabolic strategies of thermophiles and hyperthermophiles with respect to hydrocarbon oxidation.

\section{HIGH TEMPERATURE LIMITATIONS IN THE SUBSURFACE}

We hypothesize that the temperature zonation of different microbial communities and biochemistries translates into a vertical gradient or downcore sequence. How deep are the sediment layers that combine hospitable geochemical regimes and temperatures? In hydrothermal hot spots at the rift axis, microbially compatible temperature regimes are often found only near the sediment surface; downcore temperatures can increase to above $100^{\circ} \mathrm{C}$ within push coring range, ca. 30-50 cm depth (Jørgensen et al., 1990, 1992; Weber and Jørgensen, 2002; Teske et al., 2009; McKay et al., 2012). Such highly compressed temperature gradients in hydrothermal sediments are problematic for biogeographical sampling designs, since the microbial communities in these small-scale sediment gradients show a high degree of connectivity (Meyer et al., 2013). To avoid these shortcomings and to ensure a better chance of capturing biogeographical zonation in the Guaymas sediment column, sampling campaigns should move off-axis into cooler sediments characterized by lower hydrothermal heat flow and more gradual temperature (and chemical) gradients. In situ temperature gradients of the Guaymas Basin subsurface have been measured during DSDP Leg 64 in borehole 477, located in the Southern Guaymas Rift $\left(27^{\circ} 01.85 \mathrm{~N}, 111^{\circ} 23.93 \mathrm{~W} ; 2003 \mathrm{~m}\right.$ water depth) and hole 481, located at the southern end of the northern Guaymas Rift $\left(27^{\circ} 15.18\right.$ N, $111^{\circ} 30.46$ W; 1998 m water depth; Kelts etal., 1982). In situ borehole measurements for site 477 yielded temperatures of $50^{\circ} \mathrm{C}$ at $49 \mathrm{~m}$ (extrapolated equilibrium temperature) and $87^{\circ} \mathrm{C}$ at $168 \mathrm{mbsf}$ near the bottom, after $16 \mathrm{~h}$ of equilibration. For site 481, in situ borehole measurements yielded $3.6^{\circ} \mathrm{C}$ at the sediment surface, $9.0^{\circ} \mathrm{C}$ at $42 \mathrm{~m}$ depth and $56.8^{\circ} \mathrm{C}$ at $330 \mathrm{~m}$ depth, extrapolated from two temperature logs at the bottom $\left(26.2^{\circ} \mathrm{C}\right.$ after 3.5 and $51.0^{\circ} \mathrm{C}$ after $20 \mathrm{~h}$ of equilibration; Shipboard Scientific Party, 1982). The in situ mineralogy in hole 481 (sill/sediment contact metamorphism) is generally associated with temperatures below $200^{\circ} \mathrm{C}$, and the oxygen isotopic composition of recrystallized calcites near the sill contact at $170 \mathrm{~m}$ depth indicates temperatures of $130-170^{\circ} \mathrm{C}$. At site 477 , the observed greenschist facies metamorphism implies temperatures $>200^{\circ} \mathrm{C}$ below ca. $150 \mathrm{~m}$ depth. The stability of silica phases suggested exposure to hydrothermal fluids near $300^{\circ} \mathrm{C}$ (Gieskes et al., 1982a,b; Kastner, 1982). Given the lower measured temperatures at hole 477 , this hydrothermal regime must have cooled by the time of drilling. In context, the temperature measurements during DSDP leg 64 suggest that microbially compatible temperatures extend into much of the subsurface in Guaymas Basin, since drilling and sampling designs avoid the hot spreading center.

\section{ENERGETIC POTENTIAL OF GUAYMAS BASIN SEDIMENTS}

One of the key factors limiting microbial activity in any environment is energy. In order to assess the energetic landscape in Guaymas Basin sediments, geochemical data describing a representative sample of these sediments, DSDP Leg 64 Site 481A, were used to compute the Gibbs energy of redox reactions known to support microbial communities. The potential catabolic reactions chosen (Table 1) were determined by combining the likely electron donors in this setting, methane and a suite of short-chain $n$-alkanes (Whelan et al., 1988), and the only electron acceptor reported, sulfate (Gieskes et al., 1982a).

The Gibbs energy of sulfate reduction coupled to the oxidation of methane and $n$-alkanes, $\mathrm{C}_{2}-\mathrm{C}_{8}$, in Guaymas Basin sediments are shown as a function of depth in Figure 3A. Values of Gibbs energies of reaction, $\Delta G_{r}$, are given in units of kilojoules per mole of electrons transferred, $\mathrm{kJ}\left(\mathrm{mol} \mathrm{e} \mathrm{e}^{-}\right)^{-1}$ in order to facilitate comparison among the reactions. No results are shown at the depth intervals between 170 and $200 \mathrm{~m}$ and below $325 \mathrm{~m}$ due to the presence of impermeable sills. One of the more noticeable features in Figure $\mathbf{3 A}$ is that the anaerobic oxidation of methane by sulfate is thermodynamically not possible (positive values of $\Delta G_{r}$ ) throughout the sediment column (green line). However, the oxidation of all of the $n$-alkanes by sulfate have the potential to provide energy for microorganisms at all depths, ranging from about -5 to $-9 \mathrm{~kJ}\left(\mathrm{~mol} \mathrm{e}^{-}\right)^{-1}$. At almost all depths, the longer-chain alkanes provide more energy per mole of electrons transferred. Furthermore, there is little variation in energy availability as a function of depth. Because the concentration of octane was only reported at two depths at Site 481A, values of $\Delta G_{r}$ are only reported for these depths (black dots). For the other compounds, the lines represent calculations carried out at a number of depths along with interpolated values.

In Figure 3B, the Gibbs energies of the reactions listed in Table $\mathbf{1}$ are plotted as energy densities - Joules per $\mathrm{cm}^{3}$ of sediment, units that are comparable to those typically used to report biomass in sediments, i.e., cells $\mathrm{cm}^{-3}$ (LaRowe and Amend, 2014). Although the same concentration data were used to generate values of $\Delta G_{r}$ for Figures 3A,B the choice of normalizing the energy available

Table 1 | Reactions considered to provide energy for microorganisms in Guaymas basin sediments.

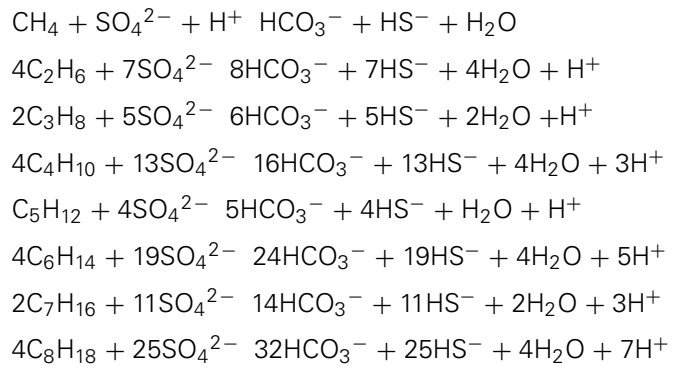



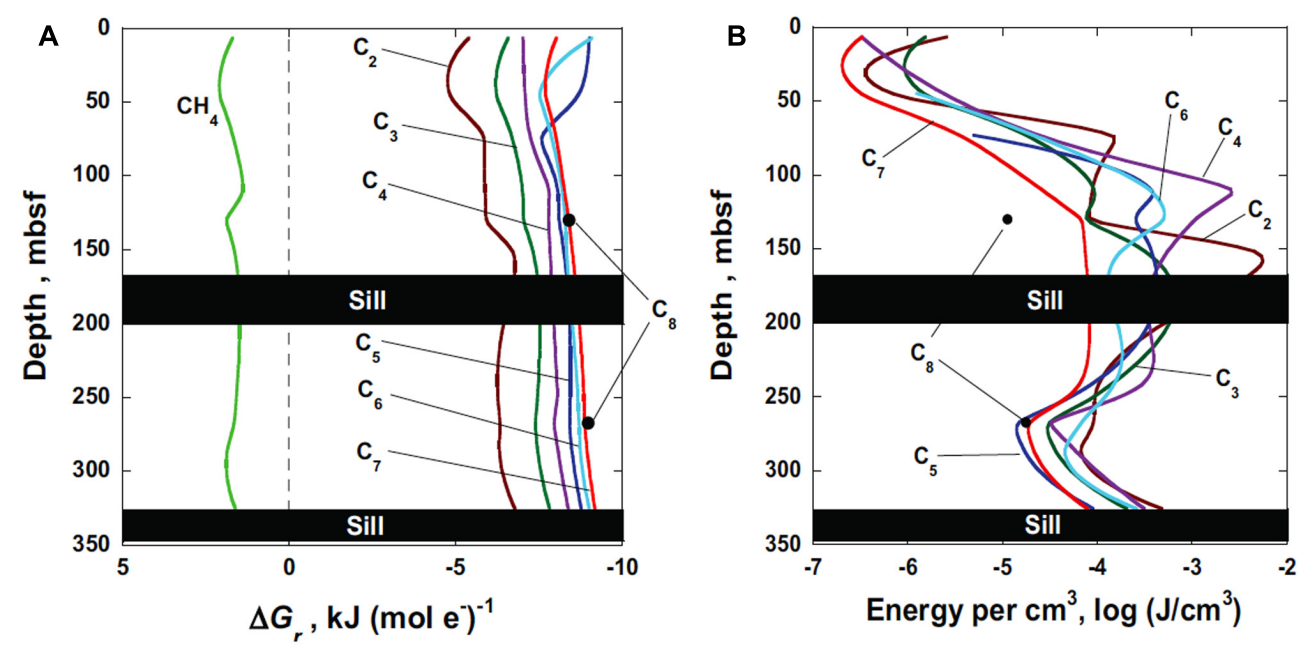

FIGURE 3 | (A) Gibbs energy of sulfate reduction, $\Delta G_{r}$, coupled to methane and $\mathrm{C}_{2}-\mathrm{C}_{8}$ n-alkane oxidation in Guaymas Basin sediments (DSDP Leg 64, Hole $481 \mathrm{~A})$ in units of Joules per mole of electrons transferred, $\mathrm{J}\left(\mathrm{mol} \mathrm{e}^{-}\right)^{-1}$. The reactions that these values of $\Delta G_{r}$ refer to are listed in Table 1.
(B) Energy availability in Guaymas Basin sediments (DSDP Leg 64, Hole $481 \mathrm{~A}$ ) in units of Joules per cubic centimeter of sediment, $\mathrm{J} \mathrm{cm}^{-3}$, calculated using the Gibbs energy of reaction and the number of moles of the limiting substrate ( $n$-alkane) in a $\mathrm{cm}^{3}$ of sediment. per mole of electrons versus per $\mathrm{cm}^{3}$ yields considerably different patterns. First of all, it should be noted that the number of Joules available per mole of electrons transferred (Figure 3A) are several orders of magnitude larger than those available per $\mathrm{cm}^{3}$ of sediment. For instance, between about $10^{-7}$ and $10^{-2} \mathrm{~J} \mathrm{~cm}^{-3}$ are available for the reactions listed in Table 1. This is due to the fact that the concentration of alkanes at Site $481 \mathrm{~A}$ are in the microto nanomolal range. That is, if all of the, e.g., heptane, were oxidized by sulfate in the shallowest portion of the sediment column (red line in Figure 3B), then a microbial community could only obtain about $10^{-6.5} \mathrm{~J} \mathrm{~cm}^{-3}$. This is substantially different than the $\sim 7500 \mathrm{~J}$ available per mole of electrons transferred for the same reaction (red line in Figure 3A).

Replotting the energetic yields of the microbial reactions (per mole of electrons transferred) as energy yield per sediment volume has interesting implications for subsurface life. For instance, whereas the energy available per mole of electrons transferred is relatively invariant with depth (Figure 3A), the amount of energy per $\mathrm{cm}^{3}$ (Figure 3B) changes by orders of magnitude as a function of depth. This can be seen for all of the reaction substrates: the energy available per $\mathrm{cm}^{3}$ from the sediment-seawater interface to the shallow sill increases by three to four orders of magnitude. Between the two sills, there is also about an order of magnitude difference in energy availability with depth. In addition, the order of which reaction provides the most energy changes from Figures 3A,B. The lighter alkanes tend to be more energy rich (Figure 3B), though there is considerable variation with depth due to crossing lines. Finally, one of the most compelling features of calculating Gibbs energies per $\mathrm{cm}^{3}$ that is not apparent in Figure $\mathbf{3 A}$, is that the amount of energy available for microbial metabolism is largest near the sills. Whether or not microorganisms are there to exploit this energy is unknown, but the potential for larger biomass numbers near the sills is evident from the much larger amount of energy that is available there.
This intriguing result suggests that the emplacement of sills in Guaymas Basin is associated with the generation of organic compounds that sulfate-reducing microorganisms are known to be able to metabolize for energy (Rüter et al., 1994; Kniemeyer et al., 2007).

\section{COMPUTATIONAL METHODS AND DATA SOURCES}

The Gibbs energies of the reactions listed in Table 1 were calculated using the revised HKF equation of state (Helgeson et al., 1981; Tanger and Helgeson, 1988; Shock et al., 1992), thermodynamic data from Shock and Helgeson (1988), Shock et al. (1989), Shock and Helgeson (1990), Sverjensky et al. (1997) and Schulte etal. (2001), the SUPCRT92 software package (Johnson et al., 1992) and compositional data from Curray and Moore (1982), Gieskes et al. (1982a) and Whelan et al. (1988). In order to carry out these calculations, the concentrations of sulfide $(0.01 \mathrm{mmol})$ and DIC ( $15 \mathrm{mmol})$ were assumed based on porewater alkalinities for sites 477 and 481 (Gieskes et al., 1982a), and limited (qualitative) sulfide detection at site 481 (Shipboard Scientific Party, 1982). Activity coefficients were calculated using the extended Debye-Hückel equation (Helgeson, 1969) and the ionic strength of seawater $(0.7 \mathrm{~mol})$. Thermal gradient data generated previously (Curray and Moore, 1982) were used to calculate the temperature as a function of depth (from $2.9^{\circ} \mathrm{C}$ at $6.6 \mathrm{~m}$ depth to $44^{\circ} \mathrm{C}$ at $325 \mathrm{~m}$ ). Porosity data generated from Einsele (1982) were used to convert the Gibbs energies of reaction per mole of substrate to Joules $\mathrm{cm}^{-3}$, using alkanes as the limiting substrate.

\section{OUTLOOK}

The temperature tolerances and energy yields of microbial processes in the Guaymas Basin subsurface strongly suggest that microbial life is capable of colonizing these hydrothermally impacted sediments to considerable depths. While the hottest sediments in hydrothermal hot spots of the spreading center are 
likely to remain beyond the range of microbial life, moderately heated sediments at a judiciously chosen distance from channelized hydrothermal flow (such as those targeted on DSDP Leg 64) provide a very reasonable chance to explore the depth extent, density, genetic and functional diversity of subsurface life under hydrothermal controls.

\section{ACKNOWLEDGMENTS}

This paper originated during a Theme Team II Subsurface Biogeography workshop on deep subseafloor drilling in Guaymas Basin, held at Wrigley Marine Station on Catalina Island, CA (February 26 to March 2, 2013). The workshop was supported by NSF Science and Technology Center for Dark Energy Biosphere Investigations (C-DEBI) and by the US Science Support Program of the International Ocean Discovery Program (IODP). This is C-DEBI publication No. 223. Douglas E. LaRowe acknowledges the NASA Astrobiology Institute based at USC, Life Underground (NAI-LU), for financial support. Amy V. Callaghan acknowledges NSF (Molecular and Cellular Biosciences, MCB-1329890) for financial support. We thank all workshop attendants for stimulating discussions on Guaymas Basin research perspectives.

\section{REFERENCES}

Abu Laban, N., Selesi, D., Rattei, T., Tischler, P., and Meckenstock, R. U. (2010). Identification of enzymes involved in anaerobic benzene degradation by a strictly anaerobic iron-reducing enrichment culture. Environ. Microbiol. 12, 2783-2796. doi: 10.1111/j.1462-2920.2010.02248.x

Aeppli, C., Carmichael, C. A., Nelson, R. K., Lemkau, K. L., Graham, W. M., Redmond, M. C., et al. (2012). Oil weathering after the Deepwater Horizon disaster led to the formation of oxygenated residues. Environ. Sci. Technol. 46, 8799-8807. doi: 10.1021/es3015138

Amend, J. P., and Teske, A. (2005). Expanding frontiers in deep subsurface microbiology. Palaeogeogr. Palaeoclimatol. Palaeoecol. 219, 131-155. doi: 10.1016/j.palaeo.2004.10.018

Bazylinski, D. A., Farrington, J. W., and Jannasch, H. W. (1988). Hydrocarbons in surface sediments from a Guaymas Basin hydrothermal vent site. Org. Geochem 12, 547-558. doi: 10.1016/0146-6380(88)90146-5

Bergmann, F. D., Selesi, D., and Meckenstock, R. U. (2011). Identification of new enzymes potentially involved in anaerobic naphthalene degradation by the sulfate-reducing enrichment culture N47. Arch. Microbiol. 193, 241-250. doi: 10.1007/s00203-010-0667-4

Biddle, J. F., Cardman, Z., Mendlovitz, H., Albert, D. B., Lloyd, K. G., Boetius, A., etal. (2012). Anaerobic oxidation of methane at different temperature regimes in Guaymas Basin hydrothermal sediments. ISME J. 6, 1018-1031. doi: 10.1038/ismej.2011.164

Bowles, M. W., Nigro, L. M., Teske, A. P., and Joye, S. B. (2012). Denitrification and environmental factors influencing nitrate removal in Guaymas Basin hydro-thermally-altered sediments. Front. Microbiol. 3:377. doi: 10.3389/fmicb. 2012.03377

Burggraf, S., Jannasch, H. W., Nicolaus, B., and Stetter, K. O. (1990). Archaeoglobus profundus sp. nov. represents a new species within the sulfate-reducing archaebacteria. Syst. Appl. Microbiol. 13, 24-28. doi: 10.1016/S0723-2020(11) 80176-1

Callaghan, A. V. (2013a). Enzymes involved in the anaerobic oxidation of $\mathrm{n}$ alkanes: from methane to long-chain paraffins. Front. Microbiol. 4:89. doi: 10.3389/fmicb.2013.00089

Callaghan, A. V. (2013b). Metabolomic investigations of anaerobic hydrocarbonimpacted environments. Curr. Opin. Biotechnol. 24, 506-515. doi: 10.1016/j.copbio.2012.08.012

Callaghan, A. V., Austin, R. N., Groves, J. T., Kukor, J. J., Rabus, R., Widdel, F., et al. (2008a). "The complete genome sequence of Desulfococcus oleovorans Hxd3, a sulfate-reducing, alkane-degrading bacterium," in American Society for Microbiology 108th General Meeting (Boston, MA: American Society of Microbiology).
Callaghan, A. V., Wawrik, B., Chadhain, S. M. N., Young, L. Y., and Zylstra, G. J. (2008b). Anaerobic alkane-degrading strain AK-01 contains two alkylsuccinate synthase genes. Biochem. Biophys. Res. Commun. 366, 142-148. doi: 10.1016/j.bbrc.2007.11.094

Callaghan, A. V., Davidova, I. A., Savage-Ashlock, K., Parisi, V. A., Gieg, L. M., Suflita, J. M., et al. (2010). Diversity of benzyl- and alkylsuccinate synthase genes in hydrocarbon-impacted environments and enrichment cultures. Environ. Sci. Technol. 44, 7287-7294. doi: 10.1021/es1002023

Callaghan, A. V., Morris, B. E. L., Pereira, I. A. C., McInerney, M. J., Kukor, J. J., Suflita, J. M., et al. (2012). The genome sequence of Desulfatibacillum alkenivorans AK01: a blueprint for anaerobic alkane oxidation. Environ. Microbiol. 14, 101-113. doi: 10.1111/j.1462-2920.2011.02516.x

Callaghan, A. V., Tierney, M., Phelps, C. D., and Young, L. Y. (2009). Anaerobic biodegradation of $n$-hexadecane by a nitrate-reducing consortium. Appl. Environ. Microbiol. 75, 1339-1344. doi: 10.1128/AEM.02491-08

Canganella, F., Jones, W. J., Gambacorta, A., and Antranikian, G. (1998). Thermococcus guaymasensis sp. nov. and Thermococcus aggregans sp. nov., two novel thermophilic archaea isolated from the Guaymas Basin hydrothermal vent site. Int. J. Syst. Bacteriol. 48, 1181-1185. doi: 10.1099/00207713-48-4-1181

Curray, J. R., Moore, D. G., and Aguayo, E. J. (1979). Leg 64 seeks evidence on development of basins. Geotimes 24, 18-20.

Curray, J. R., and Moore, D. G. (1982). Initial Reports of the Deep Sea Drilling Project, Vol. 64. Washington, DC: U.S. Government Printing Office. doi: 10.2973/dsdp.proc.64.1982

Davidova, I. A., Callaghan, A. V., Duncan, K. E., Sunner, J., Biri, B., Wawrik, B., et al. (2011). "Long-chain paraffin metabolism by a methanogenic bacterial consortium enriched from marine sediments," in 8th International Symposium of Subsurface Microbiology (Germany: Garmisch-Partenkirchen).

De la Lanza-Espino, G., and Soto, L. A. (1999). Sedimentary geochemistry of hydrothermal vents in Guaymas Basin, Gulf of California, Mexico. Appl. Geochem. 14, 499-510. doi: 10.1016/S0883-2927(98)00064-X

Dhillon, A., Teske, A., Dillon, J., Stahl, D. A., and Sogin, M. L. (2003). Molecular characterization of sulfate-reducing bacteria in the Guaymas Basin. Appl. Environ. Microbiol. 69, 2765-2772. doi: 10.1128/AEM.69.5.2765-2772.2003

Didyk, B. M., and Simoneit, B. R. T. (1989). Hydrothermal oil of Guaymas Basin and implications for petroleum formation mechanisms. Nature 342, 65-69. doi: 10.1038/342065a0

Duncan, K. E., Gieg, L. M., Parisi, V. A., Tanner, R. S., Tringe, S. G., Bristow, J., et al. (2009). Biocorrosive thermophilic microbial communities in Alaskan North Slope oil facilities. Environ. Sci. Technol. 43, 7977-798. doi: 10.1021/es9013932

Edgcomb, V. P., Molyneaux, S. J., Böer, S., Wirsen, C. O., Saito, M., Atkins, M. S., et al. (2007). Survival and growth of two heterotrophic hydrothermal vent archaea, Pyrococcus strain GB-D and Thermococcus fumicolans, under low $\mathrm{pH}$ and high sulfide concentrations in combination with high temperature and pressure regimes. Extremophiles 11, 329-342. doi: 10.1007/s00792-0060043-0

Ehrenreich, P. (1996). Anaerobes Wachstum Neuartiger Sulfatreduziernder und Nitratreduzierender Bakterien auf n-Alkanen und Erdöl. Ph.D. thesis, Universität Bremen, Germany.

Einsele, G. (1982) "Mass physical properties of Pliocene to Quaternary sediments in the Gulf of California, Deep Sea Drilling Project Leg 64" in Initial Reports of the Deep Sea Drilling Project, Vol. 64, eds J. R. Curray, J. Blakeslee, L. W. Platt, L. N. Stout, D. G. Moore, J. E. Aguayo et al. (Washington, DC: U.S. Government Printing Office), 529-542.

Einsele, G., Gieskes, J. M., Curray, J., Moore, D., Aguayo, E., Aubry, M. P., etal. (1980). Intrusion of basaltic sills into highly porous sediments and resulting hydrothermal activity. Nature 283, 441-445. doi: 10.1038/ $283441 \mathrm{a} 0$

Elsgaard, L., Isaksen, M. F., Jørgensen, B. B., Alayse, A.-M., and Jannasch, H. W. (1994). Microbial sulfate reduction in deep-sea sediments at the Guaymas Basin hydrothermal vent area: influence of temperature and substrates. Geochim. Cosmochim. Acta 58, 3335-3343. doi: 10.1016/0016-7037(94) 90089-2

Ettwig, K. F., Butler, M. K., Le Paslier, D., Pelletier, E., Mangenot, S., Kuypers, M. M., et al. (2010). Nitrite-driven anaerobic methane oxidation by oxygenic bacteria. Nature 464, 543-548. doi: 10.1038/nature08883

Galimov, E. M., and Simoneit, B. R. T. (1982). "Geochemistry of interstitial gases in sedimentary deposits of the Gulf of California, Deep Sea Drilling Project Leg 64," in Initial Reports of the Deep Sea Drilling Project, Vol. 64, eds J. R. Curray, J. 
Blakeslee, L. W. Platt, L. N. Stout, D. G. Moore, J. E. Aguayo et al. (Washington, DC: U.S. Government Printing Office), 781-787.

Gieg, L. M., Davidova, I. A., Duncan, K. E., and Suflita, J. M. (2010). Methanogenesis, sulfate reduction and crude oil biodegradation in hot Alaskan oilfields. Environ. Microbiol. 12, 3074-3086. doi: 10.1111/j.1462-2920.2010.02282.x

Gieskes, J. M., Elderfield, H., Lawrence, J. R., Johnson, J., Meyers, B., and Campbell, A. (1982a). "Geochemistry of interstitial waters and sediments," in Initial Report of the Deep Sea Drilling Project, Vol. 64, eds J. R. Curray, J. Blakeslee, L. W. Platt, L. N. Stout, D. G. Moore, J. E. Aguayo et al. (Washington, DC: U.S. Government Printing Office), 675-694.

Gieskes, J. M., Kastner, M., Einsele, G., Kelts, K., and Niemitz, J. (1982b). "Hydrothermal activity in the Guaymas Basin, Gulf of California: a synthesis," in Initial Reports of the Deep Sea Drilling Project, Vol. 64, eds J. R. Curray, J. Blakeslee, L. W. Platt, L. N. Stout, D. G. Moore, J. E. Aguayo et al. (Washington, DC: U.S. Government Printing Office), 1159-1167.

Grundmann, O., Behrends, A., Rabus, R., Amann, J., Halder, T., Heider, J., et al. (2008). Genes encoding the candidate enzyme for anaerobic activation of $n$-alkanes in the denitrifying bacterium, strain HxN1. Environ. Microbiol. 10, 376-385. doi: 10.1111/j.1462-2920.2007.01458.x

Gundersen, J. K., Jørgensen, B. B., Larsen, E., and Jannasch, H. W. (1992). Mats of giant sulfur bacteria on deep-sea sediments due to fluctuation hydrothermal flow. Nature 360, 454-455. doi: 10.1038/360454a0

Hafenbradl, D., Keller, M., Dirmeier, R., Rachel, R., Roßnagel, P., Burggraf, S., et al. (1996). Ferroglobus placidus gen nov, sp nov, a novel hyperthermophilic archaeum that oxidizes $\mathrm{Fe}^{2+}$ at neutral $\mathrm{pH}$ under anoxic conditions. Arch. Microbiol. 166, 308-314. doi: 10.1007/s002030050388

Hallam, S. J., Putnam, N., Preston, C. M., Detter, J. C., Rokhsar, D., Richardson, P. M., et al. (2004). Reverse methanogenesis: testing the hypothesis with environmental genomics. Science 305, 1457-1462. doi: 10.1126/science.1100025

He, Y., Xiao, X., and Wang, F. (2013). Metagenome reveals potential microbial degradation of hydrocarbon coupled with sulfate reduction in an oil-immersed chimney from Guaymas Basin. Front. Microbiol. 4:148. doi: 10.3389/fmicb.2013.00148

Heider, J., and Schühle, K. (2013). "Anaerobic biodegradation of hydrocarbons including methane," in The Prokaryotes: Prokaryotic Physiology and Biochemistry, 4th Edn, eds E. Rosenberg, E. F. Delong, S. Lory, E. Stackebrandt, and F. Thompson (Berlin: Springer-Verlag), 605-634.

Helgeson, H. C. (1969). Thermodynamics of hydrothermal systems at elevated temperatures and pressures. Am. J. Sci. 267, 729-804. doi: 10.2475/ajs.267.7.729

Helgeson, H. C., Kirkham, D. H., and Flowers, G. C. (1981). Theoretical prediction of thermodynamic behavior of aqueous electrolytes at high pressures and temperatures: 4. Calculation of activity coefficients, osmotic coefficients, and apparent molal and standard and relative partial molal properties to $600^{\circ} \mathrm{C}$ and $5 \mathrm{~kb}$. Am J. Sci. 281, 1249-1516. doi: 10.2475/ajs.281.10.1249

Hoehler, T. M., Alperin, M. J., Albert, D. B., and Martens, C. S. (1994). Field and laboratory studies of methane oxidation in an anoxic marine sedimentevidence for a methanogen-sulfate reducer consortium. Global Biogeochem. Cycles 8, 451-463. doi: 10.1029/94GB01800

Holler, T., Widdel, F., Knittel, K., Amann, R., Kellermann, M. Y., Hinrichs, K.-U., et al. (2011). Thermophilic anaerobic oxidation of methane by marine microbial consortia. ISME J. 5, 1946-1956. doi: 10.1038/ismej.2011.77

Holmes, D. E., Risso, C., Smith, J. A., and Lovley, D. R. (2011). Anaerobic oxidation of benzene by the hyperthermophilic archaeon Ferroglobus placidus. Appl. Environ Microbiol. 77, 5926-5933. doi: 10.1128/AEM.05452-11

Huber, R., Stöhr, J., Hohenhaus, S., Rachel, R., Burggraf, S., Jannasch, H. W., et al. (1995). Thermococcus chitonophagus sp. nov., a novel, chitin-degrading, hyperthermophilic archaeum from a deep-sea hydrothermal environment. Arch. Microbiol. 164, 255-264. doi: 10.1007/BF02529959

Jannasch, H. W., Nelson, D. C., and Wirsen, C. O. (1989). Massive natural occurrence of unusually large bacteria (Beggiatoa spp.) at a hydrothermal deep-sea vent site. Nature 342, 834-836. doi: 10.1038/342834a0

Jannasch, H. W., Wirsen, C. O., Molyneaux, S. J., and Langworthy, T. A. (1992). Comparative physiological studies on hyperthermophilic Archaea isolated from deep-sea hot vents with emphasis on Pyrococcus strain GB-D. Appl. Environ. Microbiol. 58, 3472-3481.

Jeanthon, C., L'Haridon, S., Pradel, N., and Prieur, D. (1999). Rapid identification of hyperthermophilic methanococci isolated from deep-sea hydrothermal vents. Int. J. Syst. Bacteriol. 49, 591-594. doi: 10.1099/00207713-49-2-591
Johnson, J. W., Oelkers, E. H., and Helgeson, H. C. (1992). SUPCRT92-A software package for calculating the standard molal thermodynamic properties of minerals, gases, aqueous species, and reactions from 1 bar to 5000 bar and $0{ }^{\circ} \mathrm{C}$ to $1000^{\circ}$ C. Comput. Geosci. 18, 899-947. doi: 10.1016/0098-3004(92)90029-Q

Jones, W. J., Leigh, J. A., Mayer, F., Woese, C. R., and Wolfe, R. S. (1983). Methanococcus jannaschii sp. nov., an extremely thermophilic methanogen from a submarine hydrothermal vent. Arch. Microbiol. 136, 254-261. doi: 10.1007/BF00425213

Jones, W. J., Stugard, C. E., and Jannasch, H. W. (1989). Comparison of thermophilic methanogens from submarine hydrothermal vents. Arch. Microbiol. 151, 314-319. doi: 10.1007/BF00406557

Jørgensen, B. B., Isaksen, M. F., and Jannasch, H. W. (1992). Bacterial sulfate reduction above $100^{\circ} \mathrm{C}$ in deep-sea hydrothermal vent systems. Science 258, 1756-1757. doi: 10.1126/science.258.5089.1756

Jørgensen, B. B., Zawacki, L. X., and Jannasch, H. W. (1990). Thermophilic bacterial sulfate reduction in deep-sea sediments at the Guaymas Basin hydrothermal vents (Gulf of California). Deep Sea Res. I 37, 695-710. doi: 10.1016/01980149(90)90099-H

Kallmeyer, J., and Boetius, A. (2004). Effects of temperature and pressure on sulfate reduction and anaerobic oxidation of methane in hydrothermal sediments of Guaymas Basin. Appl. Environ. Microbiol. 70, 1231-1233. doi: 10.1128/AEM.70.2.1231-1233.2004

Kallmeyer, J., Ferdelman, T. G., Jansen, K.-H., and Jørgensen, B. B. (2003). A high pressure thermal gradient block for investigating microbial activity in multiple deep-sea samples. J. Microbiol. Methods 55, 165-172. doi: 10.1016/S0167-7012(03)00138-6

Kashefi, K., Tor, J. M., Holmes, D. E., Gaw Van Praagh, C. V., Reysenbach, A. L., and Lovley, D. R. (2002). Geoglobus ahangari gen. nov., sp. nov., a novel hyperthermophilic archaeon capable of oxidizing organic acids and growing autotrophically on hydrogen with $\mathrm{Fe}$ (III) serving as the sole electron acceptor. Int. J. Syst. Evol. Microbiol. 52, 719-728. doi: 10.1099/ijs.0.01953-0

Kastner, M. (1982). "Evidence for two distinct hydrothermal systems in the Guaymas Basin," in Initial Reports of the Deep Sea Drilling Project, eds J. R. Curray, J. Blakeslee, L. W. Platt, L. N. Stout, D. G. Moore, J. E. Aguayo et al. (Washington, DC: U.S. Government Printing Office), 1143-1158.

Kawka, O. E., and Simoneit, B. R. T. (1987). Survey of hydrothermally generated petroleums from the Guaymas Basin spreading center. Org. Geochem. 11, 311328. doi: 10.1016/0146-6380(87)90042-8

Kelts, K., Curray, J. R., and Moore, D. G. (1982). "Introduction and explanatory notes," in Initial Reports of the Deep Sea Drilling Project, Vol. 64, eds J. R. Curray, J. Blakeslee, L. W. Platt, L. N. Stout, D. G. Moore, J. E. Aguayo et al. (Washington, DC: U.S. Government Printing Office), 5-26.

Khelifi, N., Amin Ali, O., Roche, P., Grossi, V., Brochier-Armanet, C., Valette, O., et al. (2014). Anaerobic oxidation of long-chain $n$-alkanes by the hyperthermophilic sulfate-reducing archaeon, Archaeoglobus fulgidus. ISME J. doi: 10.1038/ismej.2014.58 [Epub ahead of print].

Khelifi, N., Grossi, V., Hamdi, M., Dolla, A., Tholozan, J. L., Ollivier, B., et al. (2010). Anaerobic oxidation of fatty acids and alkenes by the hyperthermophilic sulfate-reducing archaeon Archaeoglobus fulgidus. Appl. Environ. Microbiol. 76, 3057-3060. doi: 10.1128/AEM.02810-09

Kimes, N. E., Callaghan, A. V., Aktas, D. F., Smith, W. L., Sunner, J., Golding, B., et al. (2013). Metagenomic analysis and metabolite profiling of deep-sea sediments from the Gulf of Mexico following the Deepwater Horizon oil spill. Front. Microbiol. 4:50. doi: 10.3389/fmicb.2013.00050

Kleindienst, S., Ramette, A., Amann, R., and Knittel, K. (2012). Distribution and in situ abundance of sulfate-reducing bacteria in diverse marine hydrocarbon seep sediments. Environ. Microbiol. 14, 2689-2710. doi: 10.1111/j.14622920.2012.02832.x

Kniemeyer, O., Fischer, T., Wilkes, H., Glöckner, F. O., and Widdel, F. (2003). Anaerobic degradation of ethylbenzene by a new type of marine sulfate-reducing bacterium. Appl. Environ. Microbiol. 69, 760-768. doi: 10.1128/AEM.69.2.760768.2003

Kniemeyer, O., Musat, F., Sievert, S. M., Knittel, K., Wilkes, H., Blumenberg, M., et al. (2007). Anaerobic oxidation of short-chain hydrocarbons by marine sulphatereducing bacteria. Nature 449, 898-901. doi: 10.1038/nature06200

Kropp, K. G., Davidova, I. A., and Suflita, J. M. (2000). Anaerobic oxidation of $n$-dodecane by an addition reaction in a sulfate-reducing bacterial enrichment culture. Appl. Environ. Microbiol. 66, 5393-5398. doi: 10.1128/AEM.66.12.53935398.2000 
Krüger, M., Meyerdierks, A., Glöckner, F. O., Amann, R., Widdel, F., Kube, M., et al. (2003). A conspicuous nickel protein in microbial mats that oxidize methane anaerobically. Nature 426, 878-881. doi: 10.1038/nature02207

Kurr, M., Huber, R., König, H., Jannasch, H. W., Fricke, H., Trincone, A., et al. (1991). Methanopyrus kandleri, gen. and sp. nov. represents a novel group of hyperthermophilic methanogens, growing at $110^{\circ}$ C. Arch. Microbiol. 156, 239 247. doi: 10.1007/BF00262992

LaRowe, D. E., and Amend, J. P. (2014). "Energetic constraints on life in marine deep sediments," in Life in Extreme Environments: Microbial Life in the Deep Biosphere eds J. Kallmeyer and K. Wagner (Berlin: De Gruyter Publishing), 279-302.

Leuthner, B., Leutwein, C., Schulz, H., Hörth, P., Haehnel, W., Schiltz, E., et al. (1998). Biochemical and genetic characterization of benzylsuccinate synthase from Thauera aromatica: a new glycyl radical enzyme catalysing the first step in anaerobic toluene metabolism. Mol. Microbiol. 28, 615-628. doi: 10.1046/j.13652958.1998.00826.x

L'Haridon, S., Reysenbacht, A.-L., Glénat, P., Prieur, D., and Jeanthon, C. (1995). Hot subterranean biosphere in a continental oil reservoir. Nature 377, 223-224. doi: $10.1038 / 377223 \mathrm{a} 0$

Lizarralde, D., Soule, A. Seewald, J., and Proskurowski, G. (2011). Carbon release by off-axis magmatism in a young sedimented spreading centre. Nat. Geosci. 4 , 50-54. doi: 10.1038/ngeo1006

Lonsdale, P., and Becker, K. (1985). Hydrothermal plumes, hot springs, and conductive heat flow in the Southern Trough of Guaymas Basin. Earth Planet. Sci. Lett. 73, 211-225. doi: 10.1016/0012-821X(85)90070-6

MacGregor, B. J., Biddle, J. F., Harbort, C., Matthysse, A. G., and Teske, A. (2013a). Sulfide oxidation, nitrate respiration, carbon acquisition and electron transport pathways suggested by the draft genome of a single orange Guaymas Basin Beggiatoa (Cand. Maribeggiatoa) sp. filament. Marine Genomics 11, 53-65. doi 10.1016/j.margen.2013.08.001

MacGregor, B. J., Biddle, J. F., Siebert, J. R., Staunton, E., Hegg, E., Matthysse, A. G., et al. (2013b). Why orange Guaymas Basin Beggiatoa spp. are orange: single-filament genome-enabled identification of an abundant octaheme cytochrome with hydroxylamine oxidase, hydrazine oxidase and nitrite reductase activities. Appl. Environ. Microbiol. 79, 1183-1190. doi: 10.1128/AEM. 02538-12

MacGregor, B. J., Biddle, J. F., and Teske, A. (2013c). Mobile elements in a singlefilament orange Guaymas Basin Beggiatoa ("Candidatus Maribeggiatoa") sp. draft genome: evidence for genetic exchange with cyanobacteria. Appl. Environ. Microbiol. 79, 3974-3985. doi: 10.1128/AEM.03821-12

Mardanov, A. V., Ravin, N. V., Svetlitchnyi, V. A., Beletsky, A. V., Miroshnichenko, M. L., Bonch-Osmolovskaya, E. A., et al. (2009). Metabolic versatility and indigenous origin of the Archaeon Thermococcus sibiricus, isolated from a Siberian oil reservoir, as revealed by genome analysis. Appl. Environ. Microbiol. 75, 4580-4588. doi: 10.1128/AEM.00718-09

Martens, C. S. (1990). Generation of short chain organic acid anions in hydrothermally altered sediments of the Guaymas Basin, Gulf of California. Appl. Geochem. 5, 71-76. doi: 10.1016/0883-2927(90)90037-6

McKay, L. J. (2014). Microbial Ecology of a Manmade Oil Spill in the Gulf of Mexico and a Natural, Hydrothermal Oil Seep in the Gulf of California. Ph.D. thesis, Department of Marine Sciences, University of North Carolina at Chapel Hill, Chapel Hill, NC.

McKay, L. J., MacGregor, B. J., Biddle, J. F., Mendlovitz, H. P., Hoer, D., Lipp, J. S., et al. (2012). Spatial heterogeneity and underlying geochemistry of phylogenetically diverse orange and white Beggiatoa mats in Guaymas Basin hydrothermal sediments. Deep Sea Res. I 67, 21-31. doi: 10.1016/j.dsr.2012.04.011

Merkel, A. Y., Huber, J. A., Chernyh, N. A., Bonch-Osmolovskaya, E. A., and Lebedinsky, A. V. (2012). Detection of putatively thermophilic anaerobic methanotrophs in diffuse hydrothermal vent fluids. Appl. Environ. Microbiol. 79, 915-923. doi: 10.1128/AEM.03034-12

Meyer, S., Wegener, G., Lloyd, K. G., Teske, A., Boetius, A., and Ramette, A. (2013). Microbial habitat connectivity across spatial scales and hydrothermal temperature gradients at Guaymas Basin. Front. Microbiol. 4:207. doi: 10.3389/fmic.2013.00207

Milucka, J., Ferdelman, T. G., Polerecky, L., Franzke, D., Wegener, G., Schmid, M., et al. (2012). Zero-valent sulphur is a key intermediate in marine methane oxidation. Nature 491, 541-546. doi: 10.1038/nature11656

Mouttaki, H., Johannes, J., and Meckenstock, R. U. (2012). Identification of naphthalene carboxylase as a prototype for the anaerobic activation of non-substituted aromatic hydrocarbons. Environ. Microbiol. 14, 2770-2774. doi: 10.1111/j.1462-2920.2012.02768.x

Musat, F., Wilkes, H., Behrends, A., Woebken, D., and Widdel, F. (2010). Microbial nitrate-dependent cyclohexane degradation coupled with anaerobic ammonium oxidation. ISME J. 4, 1290-1301. doi: 10.1038/ismej.2010.50

Nelson, D. C., Wirsen, C. O., and Jannasch, H. W. (1989). Characterization of large, autotrophic Beggiatoa spp. abundant at hydrothermal vents of the Guaymas Basin. Appl. Environ. Microbiol. 55, 2909-2917.

Oka, A. R., Phelps, C. D., Mcguinness, L. M., Mumford, A., Young, L. Y., and Kerkhof, L. J. (2008). Identification of critical members in a sulfidogenic benzenedegrading consortium by DNA stable isotope probing. Appl. Environ. Microbiol. 74, 6476-6480. doi: 10.1128/AEM.01082-08

Oremland, R. S., Culbertson, C., and Simoneit, B. R. T. (1982). "Methanogenic activity in sediment from leg 64, Gulf of California," in Initial Reports of the Deep Sea Drilling Project, Vol. 64, eds J. R. Curray, J. Blakeslee, L. W. Platt, L. N. Stout, D. G. Moore, J. E. Aguayo et al. (Washington, DC: U.S. Government Printing Office), 759-762.

Peter, J. M., Peltonen, P., Scott, S. D., Simoneit, B. R. T., and Kawka, O. E. (1991). $14 \mathrm{C}$ ages of hydrothermal petroleum and carbonate in Guaymas Basin, Gulf of California: implications for oil generation, expulsion, and migration. Geology 19, 253-256. doi: 10.1130/0091-7613(1991)019<0253:CAOHPA >2.3.CO;2

Phelps, C. D., Kazumi, J., and Young, L. Y. (1996). Anaerobic degradation of benzene in BTX mixtures dependent on sulfate reduction. FEMS Microbiol. Lett. 145, 433-437. doi: 10.1111/j.1574-6968.1996.tb08612.x

Phelps, C. D., Kerkhof, L. J., and Young, L. Y. (1998). Molecular characterization of a sulfate-reducing consortium which mineralizes benzene. FEMS Microbiol. Ecol. 27, 269-279. doi: 10.1111/j.1574-6941.1998.tb00543.x

Phelps, C. D., Zhang, Z. M., and Young, L. Y. (2001). Use of stable isotopes to identify benzoate as a metabolite of benzene degradation in a sulphidogenic consortium. Environ. Microbiol. 3, 600-603. doi: 10.1046/j.1462-2920.2001.00228.x

Rios-Hernandez, L. A., Gieg, L. M., and Suflita, J. M. (2003). Biodegradation of an alicyclic hydrocarbon by a sulfate-reducing enrichment from a gas condensate-contaminated aquifer. Appl. Environ. Microbiol. 69, 434-443. doi: 10.1128/AEM.69.1.434-443.2003

Roussel, E. G., Cambon Bonavita, M.-A., Querellou, J., Cragg, B. A., Webster, G., Prieur, D., et al. (2008). Extending the sub-seafloor biosphere. Science 320, 1046. doi: 10.1126/science.1154545

Rullkötter, J., von der Dick, H., and Welte, D. H. (1982). "Organic petrography and extractable hydrocarbons of sediment from the Gulf of California, Deep Sea Drilling Project Leg 64," in Initial Reports of the Deep Sea Drilling Project, Vol. 64, eds J. R. Curray, J. Blakeslee, L. W. Platt, L. N. Stout, D. G. Moore, J. E. Aguayo et al. (Washington, DC: U.S. Government Printing Office), 837-853.

Rüter, P., Rabus, R., Wilkes, H., Aeckersberg, F., Rainey, F. A., Jannasch, H. W., et al. (1994). Anaerobic oxidation of hydrocarbons in crude oil by new types of sulphate-reducing bacteria. Nature 372, 455-458. doi: 10.1038/372455a0

Scheller, S., Goenrich, M., Boecher, R., Thauer, R. K., and Jaun, B. (2010). The key nickel enzyme of methanogenesis catalyses the anaerobic oxidation of methane. Nature 465, U606-U697. doi: 10.1038/nature09015

Schulte, M. D., Shock, E. L., and Wood, R. (2001). The temperature dependence of the standard-state thermodynamic properties of aqueous nonelectrolytes. Geochim. Cosmochim. Acta 65, 3919-3930. doi: 10.1016/S0016-7037(01)00717-7

Shipboard Scientific Party. (1982). "Guaymas Basin: Sites 477, 478, and 481," in Initial Reports of the Deep Sea Drilling Project, Vol. 64, eds J. R. Curray, J. Blakeslee, L. W. Platt, L. N. Stout, D. G. Moore, J. E. Aguayo et al. (Washington, DC: U.S. Government Printing Office), 211-293.

Shock, E. L., and Helgeson, H. C. (1988). Calculation of the thermodynamic and transport properties of aqueous species at high pressures and temperaturescorrelation algorithms for ionic species and equation of state predictions to $5 \mathrm{~kb}$ and $1000^{\circ} \mathrm{C}$. Geochim. Cosmochim. Acta 52, 2009-2036. doi: 10.1016/00167037(88)90181-0

Shock, E. L., and Helgeson, H. C. (1990). Calculation of the thermodynamic and transport properties of aqueous species at high pressures and temperaturesstandard partial molal properties of organic species. Geochim. Cosmochim. Acta 54, 915-945. doi: 10.1016/0016-7037(90)90429-O

Shock, E. L., Helgeson, H. C., and Sverjensky, D. (1989). Calculation of the thermodynamic and transport properties of aqueous species at high pressures and temperatures-standard partial molal properties of inorganic neutral species. Geochim. Cosmochim. Acta 53, 2157-2183. doi: 10.1016/0016-7037(89)90341-4 
Shock, E. L., Oelkers, E., Johnson, J., Sverjensky, D., and Helgeson, H. C. (1992). Calculation of the thermodynamic properties of aqueous species at high pressures and temperatures-effective electrostatic radii, dissociation constants and standard partial molal properties to $1000^{\circ} \mathrm{C}$ and 5 kbar. J. Chem. Soc. Faraday Trans. 88, 803-826. doi: 10.1039/ft9928800803

Simoneit, B. R. T., and Bode, G. R. (1982). "Appendix II: carbon/carbonate and nitrogen analysis, Leg 64, Gulf of California," in Initial Reports of the Deep Sea Drilling Project, Vol. 64, eds J. R. Curray, J. Blakeslee, L. W. Platt, L. N. Stout, D. G. Moore, J. E. Aguayo et al. (Washington, DC: U.S. Government Printing Office), 1303-1305.

Simoneit, B. R. T., and Lonsdale, P. F. (1982). Hydrothermal petroleum in mineralized mounds at the seabed of Guaymas Basin. Nature 295, 198-202. doi: $10.1038 / 295198 \mathrm{a} 0$

Slobodkin, A. I., Reysenbach, A.-L., Slobodkina, G. B., Kolganova, T. V., Kostrikina, N. A., and Bonch-Osmolovskaya, E. A. (2013). Dissulfuribacter thermophilus gen. nov., sp. nov., a thermophilic, autotrophic, sulfur-disproportionating, deeply branching deltaproteobacterium from a deep-sea hydrothermal vent of the Eastern Lau Spreading Center. Int. J. Syst. Evol. Microbiol. 63, 1967-1971. doi: 10.1099/ijs.0.046938-0

So, C. M., Phelps, C. D., and Young, L. Y. (2003). Anaerobic transformation of alkanes to fatty acids by a sulfate-reducing bacterium, strain $\mathrm{Hxd} 3$. Appl. Environ. Microbiol. 69, 3892-3900. doi: 10.1128/AEM.69.7.3892-3900.2003

Sünwoldt, K., Knack, D., and Heider, J. (2012). "New reactions in anaerobic alkane and alkene metabolism," in DFG-Priority Programme 1319 Third Meeting: Biological Transformations of Hydrocarbons Without Oxygen-From the Molecular to the Global Scale (Freiburg: Deutsche Forschungsgemeinschaft).

Sverjensky, D., Shock, E. L., and Helgeson, H. C. (1997). Prediction of the thermodynamic properties of aqueous metal complexes to $1000^{\circ} \mathrm{C}$ and 5 kb. Geochim. Cosmochim. Acta 61, 1359-1412. doi: 10.1016/S0016-7037(97) 00009-4

Takai, K., Nakamura, K., Tori, T., Tsunogai, U., Miyazaki, M., Miyazaki, J., et al. (2008). Cell proliferation at $122^{\circ} \mathrm{C}$ and isotopically heavy $\mathrm{CH} 4$ production by a hyper-thermophilic methanogen under high pressure cultivation. Proc. Natl. Acad. Sci. U.S.A. 105, 10949-10954. doi: 10.1073/pnas.0712334105

Tanger, J. C., and Helgeson, H. C. (1988). Calculation of the thermodynamic and transport properties of aqueous species at high pressures and temperaturesrevised equations of state for the standard partial molal properties of ions and electrolytes. Am. J. Sci. 288, 19-98. doi: 10.2475/ajs.288.1.19

Teske, A., Edgcomb, V. P., Rivers, A. R., Thompson, J. R., de Vera Gomez, A., Molyneaux, S. J., et al. (2009). A molecular and physiological survey of a diverse collection of hydrothermal vent Thermococcus and Pyrococcus isolates. Extremophiles 13, 917-923. doi: 10.1007/s00792-009-0278-7

Teske, A., Hinrichs, K.-U., Edgcomb, V. P., de Vera Gomez, A., Kysela, D., Sylva, S. P., et al. (2002). Microbial diversity in hydrothermal sediments in the Guaymas Basin: evidence for anaerobic methanotrophic communities. Appl. Environ. Microbiol. 68, 1994-2007. doi: 10.1128/AEM.68.4.1994-2007.2002
Tor, J. M., and Lovley, D. R. (2001). Anaerobic degradation of aromatic compounds coupled to Fe(III) reduction by Ferroglobus placidus. Environ. Microbiol. 3, 281287. doi: 10.1046/j.1462-2920.2001.00192.x

Von Damm, K. L., Edmond, J. M., Measures, C. I., and Grant, B. (1985). Chemistry of submarine hydrothermal solutions at Guaymas Basin, Gulf of California. Geochim. Cosmochim. Acta 49, 2221-2237. doi: 10.1016/0016-7037(85)90223-6

von Netzer, F., Pilloni, G., Kleindienst, S., Krüger, M., Knittel, K., Gründger, F., et al. (2013). Enhanced gene detection assays for fumarate-adding enzymes allow uncovering of anaerobic hydrocarbon degraders in terrestrial and marine systems. Appl. Environ. Microbiol. 79, 543-552. doi: 10.1128/AEM.02362-12

Wang, X., Gao, Z., Xu, X., and Ruan, L. (2011). Complete genome sequence of Thermococcus sp. strain 4557, a hyperthermophilic archaeon isolated from a deep-sea hydrothermal vent area. J. Bacteriol. 193, 5544-5545. doi: 10.1128/JB. 05851-11

Wawrik, B., Mendivelso, M., Parisi, V. A., Suflita, J. M., Davidova, I. A., Marks, C. R., et al. (2012). Field and laboratory studies on the bioconversion of coal to methane in the San Juan Basin. FEMS Microbiol. Ecol. 81, 26-42. doi: 10.1111/j.15746941.2011.01272.x

Weber, A., and Jørgensen, B. B. (2002). Bacterial sulfate reduction in hydrothermal sediments of the Guaymas Basin, Gulf of California, Mexico. Deep Sea Res. I 149, 827-841. doi: 10.1016/S0967-0637(01)00079-6

Welhan, J. A. (1988). Origins of methane in hydrothermal systems. Chem. Geol. 71, 183-198. doi: 10.1016/0009-2541(88)90114-3

Whelan, J. K., Simoneit, B. R. T., and Tarafa, M. E. (1988). C1-C8 hydrocarbons in sediments from Guaymas Basin, Gulf of California-comparison to Peru Margin, Japan Trench, and California Borderlands. Org. Geochem. 12, 171-194. doi: 10.1016/0146-6380(88)90253-7

Zehnder, A. J. B., and Brock, T. D. (1979). Methane formation and methane oxidation by methanogenic bacteria. J. Bacteriol. 137, 420-432.

Conflict of Interest Statement: The authors declare that the research was conducted in the absence of any commercial or financial relationships that could be construed as a potential conflict of interest.

Received: 12 May 2014; accepted: 26 June 2014; published online: 31 July 2014. Citation: Teske A, Callaghan AV and LaRowe DE (2014) Biosphere frontiers of subsurface life in the sedimented hydrothermal system of Guaymas Basin. Front. Microbiol. 5:362. doi: 10.3389/fmicb.2014.00362

This article was submitted to Extreme Microbiology, a section of the journal Frontiers in Microbiology.

Copyright (c) 2014 Teske, Callaghan and LaRowe. This is an open-access article distributed under the terms of the Creative Commons Attribution License (CC BY). The use, distribution or reproduction in other forums is permitted, provided the original author(s) or licensor are credited and that the original publication in this journal is cited, in accordance with accepted academic practice. No use, distribution or reproduction is permitted which does not comply with these terms. 